\title{
Research on the Embodiment and Protection of Workers' Rights and Interests in the New Individual Income Tax Law of The P.R.C.
}

\author{
Xin Luo* \\ Department of Accounting, School of Economics and Management, Beijing Jiaotong University \\ *Corresponding author. Email:18610019446@163.com
}

\begin{abstract}
The Individual Income Tax Law of the People's Republic of China ("the new Tax Law"), which was formally implemented on January 1, 2019, protects the workers' rights and interests in the calculation methods and design ideas of individual income tax. This paper will try to analyze concretely how to protect the workers' rights and interests in the aspects of calculation methods and design ideas of the new tax law, especially in the collection of comprehensive labor income tax and the adjustment of comprehensive income tax rate.
\end{abstract}

Keywords: Workers' rights and interests, New tax law, Individual income tax, Taxable income.

\section{FOREWORD}

On January 1, 2019, the Individual Income Tax Law of the People's Republic of China ("the new Tax Law") was formally implemented, and the supporting rules and implementation regulations on the special additional deduction of individual income tax were promulgated, which formed multiple guarantees for the collection and management of individual income tax. Moreover, compared with the previous individual income tax, the new Tax Law has formally implemented the combination of the Classified Tax System and the Comprehensive Tax System modes. By setting up the comprehensive tax items of labor income, the expense deduction standard is refined, and the comprehensive income tax rate is adjusted correspondingly, reflecting and protecting the workers' rights and interests.

\section{EMBODIMENT OF THE}

\section{CALCULATION METHODS IN THE NEW TAX LAW ON THE WORKERS' RIGHTS AND INTERESTS}

In the formulation and implementation of the new Tax Law in China, optimizing the mode of individual income tax is an important goal and content. It reflects that the new Tax Law's protection on the workers' rights and interests mainly through the tax rate, tax base and other related elements, and reflects social equity and efficiency from different angles. Since 1977 when the United Kingdom started to collect individual income tax for the first time, with respect to the collection and management of individual tax income, various countries have always adopted three modes, i.e. Classified Tax System, Dual Tax System and Comprehensive Tax System, which has formed a classified and comprehensive income tax system, a mixed tax system and a diversified tax system. Each tax system adopts different design ideas when formulating tax rate and calculating tax base, which has an impact on the basic income and additional welfare tax of individual income of workers, and finally measures the life index of workers.

\subsection{Labor Income is an Important Part of Individual Taxable Income}

In the personal income tax, it mainly includes the related contents such as factor remuneration and transfer income. Moreover, in modern economics, labor income of workers is also classified into the category of factor remuneration. Individual income tax, in essence, belongs to the link and content of redistributing personal wealth. It is that individuals turn over part of their income to the state free of charge under the premise of obtaining corresponding public services. Compared with capital gains tax, personal income tax is a process in which workers obtain wealth through personal labor. 
Different from the transfer payment of public and private sectors, labor income, business income and investment income belong to the category of factor remuneration in the primary distribution system of national income.

According to the basic relationship, labor income can be further divided into two different types, which are independent labor income and employment labor income. According to the connotation of workers in Labor Law of the People's Republic of China, the important basis for determining the identity of laborers is the stability and effectiveness of labor relations. The protection of workers' rights and interests in the new Tax Law mainly lies in that the taxable amount of labor income is more reasonable. In the individual income tax, although labor income is the secondary classification of individual taxable income, it is the tax source with the most extensive foundation. In China's tax structure, the proportion of labor income in the source of residents' income is declining, but the proportion in individual income tax is rising. Therefore, whether from the perspective of theoretical classification or from the contribution rate of individual income tax amount, labor income is always the highest proportion of individual taxable income.

\subsection{The Protection of Workers' Rights and Interests in the Selection of Individual Income Tax Mode in the new Tax Law}

The individual income tax has gradually developed into three individual income tax modes since it come into being. Among them, the Comprehensive Tax System is to collect the comprehensive income in a certain period of time, which mainly adopts the calculation method of progressive tax rate; the
Classified Tax System emphasizes that different tax rates and different deductions are adopted when collecting individual income tax. Generally, there is a low cost of tax collection and management in the early stage of individual income tax development; the Dual Tax System is based on the characteristics of the former two tax systems, further divided into two different forms, which are "Comprehensive Classification Tax System" and "Classified Comprehensive Tax System". The Comprehensive Tax System is the basis of the Comprehensive Classification Tax System, which collects individual income tax on some specific items; the Classified Comprehensive Tax System is premised on the classified collection and payment, which is based on the Classified Tax System, and collects the comprehensive income tax on the excess part. As the most important part of the individual income tax mode, the actual income of workers' wages will be different due to the design of different elements of different tax systems, which has an indirect impact on the workers' rights and interests.

In Table 1, it can be found that "tax base category" and "tax rate range" have a direct impact on the final tax amount of workers. Moreover, for workers, because of the different calculation methods, under different individual income tax modes, the total individual taxable amount is also different. According to the classified tax payment based on "Classified Tax System" in China's implemented tax laws before 2018, the new Tax Law in 2018 puts wage and salary income, as well as labor remuneration, into the comprehensive income category of workers for calculation and collection. Among them, labor remuneration and wages are RMB 10,000 yuan respectively and social security cost is RMB 300 yuan per month, and there are no other deductions:

Table 1. Individual Income Tax Calculation Methods in Different Tax Systems

\begin{tabular}{|c|c|c|c|}
\hline \multicolumn{3}{|c|}{ Individual Income Tax System Mode } & Calculation Method \\
\hline \multirow{3}{*}{$\begin{array}{l}\text { Classified } \\
\text { Income Tax } \\
\text { System } \\
\end{array}$} & \multicolumn{2}{|c|}{ Multivariate Classification } & Diversified Division of Income Types \\
\hline & \multicolumn{2}{|c|}{ Binary Classification } & Business Income, Capital Income and Labor Income \\
\hline & \multicolumn{2}{|c|}{ Ternary Classification } & Capital Income and Labor Income \\
\hline \multirow{4}{*}{$\begin{array}{l}\text { Comprehensiv } \\
\text { e Income Tax } \\
\text { System }\end{array}$} & \multirow{2}{*}{$\begin{array}{l}\text { Single-stage } \\
\text { Integration }\end{array}$} & Quasi Single-stage Integration & $\begin{array}{l}\text { Proportional Tax Rate } * \text { Ordinary Income } \\
\text { Proportional Tax Rate } * \text { Special Income }\end{array}$ \\
\hline & & Pure Single-stage Integration & Proportional Tax Rate* Total Income \\
\hline & \multirow{2}{*}{$\begin{array}{l}\text { Multi-stage } \\
\text { Integration }\end{array}$} & Quasi Multi-stage Integration & $\begin{array}{l}\text { Progressive Tax Rate*Ordinary Income } \\
\text { Proportional Tax Rate* Special Income }\end{array}$ \\
\hline & & Pure Multi-stage Integration & Progressive Tax Rate $*$ Total Income \\
\hline \multirow{2}{*}{$\begin{array}{l}\text { Dual Tax } \\
\text { System }\end{array}$} & \multicolumn{2}{|c|}{ Comprehensive Classification } & $\begin{array}{l}\text { Comprehensive income tax surcharge + classified } \\
\text { income tax }\end{array}$ \\
\hline & \multicolumn{2}{|c|}{ Classified integration } & $\begin{array}{l}\text { Classified income tax surcharge + Comprehensive } \\
\text { income tax }\end{array}$ \\
\hline
\end{tabular}


In the calculation process of individual income tax, if the classified tax system mode is adopted and the tax is paid according to the "wage and salary income" tax item, the taxable amount $=$ (wage and salary income social security expense - deduction amount) $*$ applicable tax rate - quick calculation deduction amount $=(10,000$ $300-3,500) * 20 \%-555=\mathrm{RMB} 685$ yuan; if the tax is paid according to the tax item of "income from labor remuneration", the individual income should be paid = income from labor remuneration * (1 - proportional tax rate) * applicable tax rate - quick calculation deduction amount $=10000 *(1-20 \%) * 20 \%-0=\mathrm{RMB} 1,600$ yuan. Therefore, in the classified tax system mode, due to the different tax items it belongs to, the amount of tax payable varies greatly, which has an impact on the aftertax income of workers. Therefore, if both of them are classified as "comprehensive income", and the year is taken as the tax payment time unit, and the standard is relatively unified, the two taxable amounts are basically the same, so as to fully respect and protect the income rights and interests of workers.

\section{THE EMBODIMENT AND PROTECTION OF WORKERS' RIGHTS AND INTERESTS BY THE DESIGN IDEA OF NEW TAX LAW}

The Individual Income Tax Law of the People's Republic of China, which was formally passed on August 31, 2018, is the formal transformation of China's individual income tax system from Classified Tax System to Classified Comprehensive Dual Tax System. In accordance with the old Tax Law, the individual income tax system has always adopted the individual income tax system mode. The calculation and collection of individual income tax are classified and collected separately, and the tax is withheld from the source classification tax system. However, this kind of tax mode has been unable to effectively meet the needs of the rapid development of modern society. At the same time, due to the enumerated tax items and legal provisions, the expression is also vague, which leads to the unfair tax burden. Moreover, because the Classified Tax System takes different treatments for all kinds of income tax, for workers, although the income deduction standard and tax rate from different sources are different, it may lead to different payment of individual income tax for workers with the same income, which affects the purpose of income adjustment by individual income tax and also affects the workers' psychology of tax payment to a certain extent. Therefore, the comprehensive tax system mode adopted by the new Tax Law not only pursues social equity, but also protects the legal rights and interests of "same income and same tax" of workers.

\subsection{The Reform of Individual Income Tax Mode in the New Tax Law Protects the Workers' Rights and Interests}

Promoting and ensuring equitable distribution is the main social function and core task of Tax Law. Since its implementation in 1980, China's Individual Income Tax System has basically taken the Classified Taxation System as the main body. In order to give consideration to fairness and efficiency, the Tax Law further classifies it and strives to achieve social equity in the secondary distribution of wealth by means of addition collection. However, it also causes more complicated problems in the calculation and collection of individual income tax in the Tax Law, which not only did not fully realize fairness, but also caused the loss of efficiency in a sense. At the same time, in the Classified Tax System, there is no fairness in the number of individual income tax source items. In other words, workers with less item sources and lower comprehensive income bear more tax burdens, while whose with more item sources and higher comprehensive income may bear less tax burdens.

In the process of design, calculation and collection of individual income tax, the new Tax Law has made clear the different tax payment scopes for individual subjects of non-tax residents and tax residents. At the same time, it has added corresponding anti-tax avoidance provisions to optimize the tax collection and management mode. At the same time, it has carried out classification design in the individual income tax mode, which fully embodies the workers' rights and interests. According to Table 1, it can be found that the definition of income category and the selection of tax rate range in the individual income tax mode will have different effects on the workers' rights and interests. Based on the calculation of the categories and tax rate design of individual income tax in the tax laws of 1980, 1986 1993 and 2018 in China, this paper focuses on the two items of "income from labor remuneration" and "income from wages and salaries", and analyzes the impact of individual mode selection and workers' rights and interests in the new and old tax laws. 
Table 2. Individual Income Tax Classification and Tax Rate Changes in Previous Tax Laws of China

\begin{tabular}{|c|c|c|}
\hline & Classification & Tax Rate \\
\hline \multirow{2}{*}{$\begin{array}{l}\text { Tax Law } \\
\text { of } 1980\end{array}$} & Wages and Salaries & $5 \%-45 \%$ \\
\hline & $\begin{array}{l}\text { Labor Remuneration; Royalty; Capital Income; Property } \\
\text { Leasing; Others }\end{array}$ & $20 \%$ \\
\hline \multirow[b]{2}{*}{$\begin{array}{l}\text { Tax Law } \\
\text { of } 1986\end{array}$} & $\begin{array}{l}\text { Wages and Salaries; Contract and Subcontract; Labor } \\
\text { Remuneration; Property Leasing }\end{array}$ & $\begin{array}{c}20 \%-60 \% \text { of progressive tax in excess of specific } \\
\text { amount }\end{array}$ \\
\hline & $\begin{array}{c}\text { Income from Patent Right Transfer, Patent Licensing and } \\
\text { Provision and Transfer of Non-Patented Technology; } \\
\text { Income from Contribution and Translation; Capital } \\
\text { Income }\end{array}$ & $20 \%$ of proportional tax \\
\hline \multirow{3}{*}{$\begin{array}{l}\text { Tax Law } \\
\text { of } 1993\end{array}$} & Wages and Salaries & $\begin{array}{c}4 \%-45 \% \text { of progressive tax in excess of specific } \\
\text { amount }\end{array}$ \\
\hline & $\begin{array}{c}\text { Production and Operation Income of Individual } \\
\text { Businesses; Operating Income from Contracting or } \\
\text { Leasing }\end{array}$ & $\begin{array}{l}5 \%-35 \% \text { of progressive tax in excess of specific } \\
\text { amount }\end{array}$ \\
\hline & $\begin{array}{l}\text { Remuneration for Labor Service; Remuneration for } \\
\text { Contribution; Royalty; Capital Income; Income from } \\
\text { Property Leasing; Income from Property Transfer; } \\
\text { Occasional Income; Other Income }\end{array}$ & $20 \%$ of proportional tax \\
\hline \multirow{3}{*}{$\begin{array}{l}\text { Tax Law } \\
\text { of } 2018\end{array}$} & $\begin{array}{l}\text { Wages and Salaries; Remuneration for Labor Service; } \\
\text { Remuneration for contribution; Royalty }\end{array}$ & $\begin{array}{l}\text { Individual is calculated by annual consolidation; non- } \\
\text { resident individual is itemized and calculated by } \\
\text { month or by times }\end{array}$ \\
\hline & Operating Income & $\begin{array}{c}5 \%-35 \% \text { of progressive tax in excess of specific } \\
\text { amount }\end{array}$ \\
\hline & $\begin{array}{l}\text { Capital Income; Property Leasing Income; Property } \\
\text { Transfer Income; Occasional Income }\end{array}$ & $20 \%$ of proportional tax \\
\hline
\end{tabular}

Through calculation and comparison, we can find that, from the perspective of individual income tax, both wage and salary income and labor remuneration income are related to workers' rights and interests. In China's tax laws, although both of them belong to the scope of income, there are great differences in the calculation of tax rates. In particular, in the new Tax Law of 2018, both are combined into "comprehensive income", and were divided according to the individual resident subjects and non-individual resident subjects, and were classified by the tax payment time nodes and calculation methods. Compared with the calculation methods in previous tax laws, the calculation method is more detailed and clearer. Among them, the biggest advantage of calculating and collecting the comprehensive income of workers in a period of time is to reflect the comprehensive tax payment ability of workers. Moreover, compared with the previous tax laws, the high-income groups have a wide range of income sources, so it is applicable to the classified tax rules. However, for workers with a single income source, their tax advantages are not obvious, and the high-income groups have diversified tax avoidance space. Therefore, in terms of actual tax burden, it is more obvious than that of low-income groups, so it is unable to reflect the comprehensive and true tax-bearing capacity of taxpayers.

\subsection{Protection of Workers' Rights and Interests in the New Tax Law}

From the perspective of micro rules, the selection of individual income tax mode in the new Tax Law, reflects the protection of workers' rights and interests through the collection of comprehensive labor income tax and the adjustment of comprehensive income tax rate:

First, the comprehensive taxation on labor income reflects the protection of workers' rights and interests. The establishment of comprehensive taxation on labor income changes the calculation and collection mode of individual income tax, affects the design of tax base category, and reflects the categories and items of taxable income of workers. From the perspective of fairness, the comprehensive calculation and collection of new Tax Law individual income tax mode can indeed reduce the tax burden of taxpayers with different income sources but the same income level, reflecting the horizontal fairness of the tax law, and requiring the same amount 
of tax paid by people with the same income. In the individual income tax mode of the new Tax Law, such as wages and salaries, remuneration for personal services, royalties, and the ideological labor income, such as remuneration for contributions are combined into "comprehensive income", and the individual income tax is calculated on an annual basis in the way of comprehensive taxation. It is mainly considered that there are many similarities between the above four tax items, and they are directly related to the workers themselves. The above four tax items belong to the labor income of the workers, especially in terms of wages, salaries and remuneration for personal services, but also the daily property income obtained through their own labor. Therefore, the individual mode has a direct impact on the workers' rights and interests.

Second, the comprehensive income tax rate has been adjusted to protect the rights and interests of workers. In order to reflect the fairness and efficiency of taxation, other countries in the world basically adopt the way of combining "low tax rate" and "wide tax base" to levy individual income tax. The new Tax Law calculates and collects the income tax on wages and salaries in the original mode of 7-level progressive tax rate in excess of specific amount, thus widening the range of middle and low-level tax rates, reflecting the "low tax rate" and giving more care to the middle and low income groups. Compared with the three-tier tax rates of $3 \%, 10 \%$ and $20 \%$ before enforcing the new Tax Law, the tax level change in the first three quarters is relatively obvious, and the tax rate range of $3 \%$ is doubled. In other words, the new Tax Law will reduce the tax rate by $3 \%$ for people with income being taxed at the tax rate of $10 \%$, which will greatly reduce the tax payment for the middle and low income groups. By optimizing the change of tax rate, the tax burden of workers is reduced, the workers' rights and interests are protected, and their quality of life and living standard are improved.

\section{CONCLUSION}

To sum up, the promulgation and implementation of the new tax law has made more comprehensive and scientific provisions on strengthening the protection of workers' rights and interests. No matter from the design idea of the new tax law or the calculation method of the new tax law, its implementation has an important role in safeguarding workers' legitimate rights and interests, reflecting social fairness and rationality, maintaining social harmony and stability, and promoting social development and progress effect. As the relevant departments and individual workers, they should seriously study and implement the contents of the new tax law, safeguard the authority of the law, increase publicity, and create better conditions for better implementation of the new tax law and safeguarding the legitimate rights and interests of workers.

\section{REFERENCES}

[1] Ji Jie. Research on Laborers' Rights and Interests under the New Tax Law Model [J]. Taxation and Economy, 2020(1): 71-78.

[2] Shen MinRong, Yao JiDong. Tax Equity in Modern Society: The Influence of Justice Thought on Modern Tax System [J].Theory and Reform, 2018, (4): 46-49.

[3] Xing Huiqiang. Classification Rules and Comprehensive Regulation of Individual Income [J]. Journal of East China University of Political Science and Law, 2019, (1): 39-44. 